\title{
CHEMOSPHERE
}

\section{Phosphine and methane generation by the addition of organic compounds containing carbon-phosphorus bonds into incubated soil}

\author{
S.H. Han ${ }^{\text {a }}$, Y.H. Zhuang ${ }^{\text {a,* }}$, H.X. Zhang ${ }^{\text {a }}$, Z.J. Wang ${ }^{\text {a,b }}$, J.Z. Yang ${ }^{\text {a }}$ \\ ${ }^{a}$ Research Center for Eco-Environmental Sciences, Chinese Academy of Sciences, P.O. Box 2871, Beijing 100085, China \\ b The State Key Laboratory of Aquatic Chemistry, P.O. Box 2871, Beijing 100085, China
}

Received 19 November 2001; received in revised form 19 June 2002; accepted 9 July 2002

\begin{abstract}
Formation of phosphine and methane in anaerobic incubation systems was investigated under stirred and unstirred conditions. The $\mathrm{PH}_{3}$ and $\mathrm{CH}_{4}$ levels in the headspace, as well as the matrix-bound $\mathrm{PH}_{3}$ content in the stirred soil, significantly increased upon the addition of phosphonoacetic acid $\left(\mathrm{P}(\mathrm{O})(\mathrm{OH})_{2} \mathrm{CH}_{2} \mathrm{COOH}\right)$. Both the levels of matrixbound $\mathrm{PH}_{3}$ and $\mathrm{CH}_{4}$ are positively correlated to the buffered dithionite fraction of reactive phosphorus in the soil samples, while a negative correlation was observed between matrix-bound $\mathrm{PH}_{3} / \mathrm{CH}_{4}$ levels and the reactive phosphorus fraction.
\end{abstract}

(c) 2002 Elsevier Science Ltd. All rights reserved.

Keywords: Phosphine; Methane; Anaerobic fermentation; Phosphonoacetic acid; Reactive phosphorus

\section{Introduction}

The hypothesis that microbial phosphate reduction is the predominant mechanism responsible for phosphine formation is subject to controversial discussion (Barrenscheen and Beckh-Widmanstetter, 1923; Tsubota, 1959; Iverson, 1968). Because of their insufficient analytical techniques for phosphine detection, the abovementioned authors could not provide convincing evidence on phosphine formation. The occurrence of phosphine in the natural environment has remained in dispute for nearly half a century. Since the enrichment and analytical techniques for ambient phosphine were improved, phosphine has been detected from numerous anaerobic sources (Gassmann and Schorn, 1993; Gassmann, 1994; Devai and Delaune, 1995; Glindemann and Bergmann,

\footnotetext{
${ }^{*}$ Corresponding author. Tel.: +86-10-62923564; fax: +86-1062923563.

E-mail address: zhuangyh@sun.ihep.ac.cn (Y.H. Zhuang).
}

1995; Glindemann et al., 1996a,b; Devai et al., 1988; Liu et al., 1999; Han et al., 2000). Han et al. (2000) reported the seasonal variation of phosphine flux from paddy fields.

However, the mechanism of phosphine formation remained unclear. Some tentative experimental results indicated that addition of chicken manure, bone powder, or lecithin can lead to an increment of phosphine emission (Eismann et al., 1997a; Cao et al., 2000). Moreover, Eismann et al. (1997b) found a correlation between the evolution of phosphine and the production of methane/hydrogen sulfide during anaerobic fermentation of fresh swine manure. Bayer et al. (1972) identified phosphinothricin, a microbial secondary metabolite with a $(+1)$-phosphorus atom in its molecule. In all the cited reports, phosphine and matrix-bound phosphine have been reported to be a minor fraction of the organic phosphorus in soil and sediment. Not all the organic phosphorus can be converted to phosphine. This implies that the major constituents of organic phosphorus, which are esters of phosphoric acid, cannot be 
reduced directly to phosphine. Phosphine should be derived from organic compounds other than phosphates.

In this study, we turned to organic phosphorus compounds with $\mathrm{C}-\mathrm{P}$ bonds. These organic phosphorus compounds are available in the environment, but in minor quantities. The first organic phosphorus compound with a $\mathrm{C}-\mathrm{P}$ bond identified in the environment was 2-aminoethylphosphonic acid, which was isolated from rumen protozoa by Horiguchi and Kandatsu (1959). Alkylphosphonates were then reported to occur widely in nature, combined either in lipids (Rosenberg, 1973), or in polysaccharides (Korn et al., 1973), and in proteins as well (Hilderbrand et al., 1973; Hilderbrand and Henderson, 1983). Phosphonates have also been found in bacteria, fungi, and higher organisms, such as the snail schistosome vector Biomphalaria (Mastalerz, 1984; Thompson and Lee, 1985). Although alkylphosphonates are regarded as having great chemical stability as a result of their $\mathrm{C}-\mathrm{P}$ bonds, it has been found that bacteria are capable of using different alkylphosphonates as substrates, which are isolated from sewage and soil (Cook et al., 1978). Daughton et al. (1979) reported that bacteria caused $\mathrm{C}-\mathrm{P}$ bond cleavage to yield alcohols, alkanes and inorganic phosphates. Nevertheless, these authors have not tried to detect the presence of phosphine during $\mathrm{C}-\mathrm{P}$ bond cleavage.

It is, therefore, the purpose of this study to investigate phosphine and methane generation upon the addition of organic compounds containing carbonphosphorus bonds into incubated soil. The compound we used in our study (phosphonoacetic acid, PA) is a biogenic phosphonate found by Hilderbrand and Henderson (1983).

\section{Materials and methods}

\subsection{Anaerobic fermentation experiments}

For anaerobic fermentation experiments, we used a paddy soil sample taken from Houbajia, Beijing as the culture inoculum. Aliquots of $3-\mathrm{kg}$ thoroughly mixed inoculum were put separately into two 20-1 glass thermostated fermentors together with 51 of water. In one of these fermentors, $1.03 \mathrm{~g}$ of phosphonoacetic acid $\left(\mathrm{P}(\mathrm{O})(\mathrm{OH})_{2} \mathrm{CH}_{2} \mathrm{COOH}, 98 \%\right.$, Aldrich Chem. Co.) was added too. It is equivalent to an increment of $0.076 \mathrm{mg}$ $\mathrm{P}$ per gram of dry soil. In the other fermentor, which served as a control, no phosphonoacetic acid was introduced. The two fermentors were at first evacuated to remove air, and were then purged with high-purity nitrogen. This manipulation was repeated twice. To prevent air intrusion into the anaerobic fermentors, the outlets of the fermentors were isolated from ambient air by liquid seals. Then the fermentors were incubated in darkness at $30 \pm 1{ }^{\circ} \mathrm{C}$ with magnetic stirring. Incubation time was about one month. Four to six parallel gas samples from the headspace were taken with $50-\mathrm{ml}$ plastic syringes every day or every other day. At the end of experiments, the matrix-bound phosphine levels and reactive phosphorus levels in the incubated soil samples were determined.

A second batch of anaerobic incubation experiments was run under unstirred conditions. About 40-g aliquots of paddy soil were weighed and added to $120-\mathrm{ml}$ glass vials together with $50-\mathrm{ml}$ water. To one group of vials, 0 , 100,200 , and $300 \mathrm{mg}$ of phosphonoacetic acid were added, respectively. To the other group of vials, $\mathrm{NaOH}$ and $\mathrm{H}_{2} \mathrm{SO}_{4}$ solutions were added to adjust the $\mathrm{pH}$ value to $4.85,6.74$, and 8.2 , respectively. All the vials were then purged with high-purity nitrogen for $5 \mathrm{~min}$, and were stoppered with septa. For each substrate studied, six vials and two controls were run in parallel. The sealed vials were then incubated without agitation at $30 \pm 1{ }^{\circ} \mathrm{C}$ under a dark cover. Headspace gas samples were then taken with the aid of two $50-\mathrm{ml}$ plastic syringes. High-purity nitrogen in one syringe with a long needle $(10 \mathrm{~cm})$ was injected through the sediment into the vial, while the other empty syringe with a short needle $(2 \mathrm{~cm})$ was used to take headspace gas from the same vial simultaneously. The headspace gas samples, as well as the matrix-bound phosphine samples liberated from soil samples, were subjected to GC analysis as described elsewhere (Glindemann and Bergmann, 1995; Liu et al., 1999; Cao et al., 2000; Han et al., 2000).

\subsection{Matrix-bound phosphine collection and the determi- nation of phosphine and methane}

The procedures for matrix-bound phosphine collection and phosphine determination described by Glindemann and Bergmann (1995) and by Han et al. (2000) were adopted in this study. Methane was measured by GC-FID.

\subsection{Total phosphorus and reactive phosphorus detection}

Total phosphorus detection follows the procedures described in the Handbook of Agro-Chemistry Analysis (Li et al., 1984).

Sequential fractionation of reactive phosphorus (RP) was performed according to the procedure described by $\mathrm{Fu}$ et al. (2000). Incubated soil samples in acid-washed polypropylene tubes were at first centrifuged for $20 \mathrm{~min}$

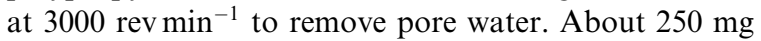
of the "de-watered" sediment was placed in a $50-\mathrm{ml}$ acid-washed centrifuge tube, and subjected to sequential extraction according to the procedures listed in Table 1 (Fu et al., 2000). The supernatants of each extraction after centrifugation for $10 \mathrm{~min}$ at $3000 \mathrm{rev} \mathrm{min}^{-1}$ were analyzed for molybdate reactive phosphorus (MRP) 
Table 1

Extraction scheme and fractional composition of reactive phosphorus in soil samples

\begin{tabular}{|c|c|c|}
\hline Extraction medium & $\begin{array}{l}\text { Fraction } \\
\text { acronym }\end{array}$ & Main species \\
\hline $\mathrm{H}_{2} \mathrm{O}$ (for $\left.10 \mathrm{~min}\right)$ & $\mathrm{H}_{2} \mathrm{O}-\mathrm{RP}$ & Orthophosphate, $o-\mathrm{P}$ \\
\hline $\mathrm{BD}\left(0.11 \mathrm{moll}^{-1}\right.$ buffered sodium dithionite for $30 \mathrm{~min}$ at $\left.40^{\circ} \mathrm{C}\right)$ & BD-RP & Reductant soluble P, RSP (iron-bound P) \\
\hline $\begin{array}{l}\mathrm{NaOH}\left(1.0 \mathrm{moll}^{-1} \text { sodium hydroxide for } 16 \mathrm{~h} \text { at room }\right. \\
\text { temperature) }\end{array}$ & $\mathrm{NaOH}-\mathrm{RP}$ & Iron-bound $\mathrm{P}(\mathrm{Fe}-\mathrm{P})$ \\
\hline $\mathrm{HCl}\left(0.5 \mathrm{moll}^{-1}\right.$ hydrochloric acid for $24 \mathrm{~h}$ at room temperature $)$ & HCl-RP & Calcium- and magnesium-bound $\mathrm{P}(\mathrm{Ca}, \mathrm{Mg}-\mathrm{P})$ \\
\hline $\mathrm{NaOH}\left(1.0 \mathrm{moll}^{-1}\right.$ sodium hydroxide for $24 \mathrm{~h}$ at $\left.85^{\circ} \mathrm{C}\right)$ & $\begin{array}{l}\mathrm{NaOH}-\mathrm{RP} \\
\left(85^{\circ} \mathrm{C}\right)\end{array}$ & $\begin{array}{l}\text { Refractory } \mathrm{P} \text {, inorganic or organic poly- } \\
\text { phosphates }\end{array}$ \\
\hline
\end{tabular}

(Murphy and Riley, 1962). All analyses were run in triplicate, and the MRP results were given on a dryweight basis (dw).

\section{Results and discussion}

\subsection{Phosphine and methane levels in the headspace of fermentors}

A soaring increase of $\mathrm{PH}_{3}$ and $\mathrm{CH}_{4}$ levels was observed in the headspace of the fermentor with phosphonoacetic acid (Fig. 1). The $\mathrm{PH}_{3}$ level in this fermentor was 100 -folds as high as that in the control. The $\mathrm{CH}_{4}$ level was about 3-5-fold more than that in the control. Furthermore, the duration of $\mathrm{PH}_{3}$ and $\mathrm{CH}_{4}$ release with phosphonoacetic acid added was longer than that in the control. Further investigation is needed to elucidate the causes of this phenomenon.
In our fermentation experiments with a small amount of phosphonoacetic acid added, we did not observe the inhibition effect of phosphine to methane formation. This is in agreement with Eismann's observation that anaerobic fermentation of acetate and yeast extracts was not affected by the presence of $\mathrm{PH}_{3}$ up to $1000 \mathrm{ppm}$ (Eismann et al., 1997c).

We found that the first $\mathrm{CH}_{4}$ peak appeared about nine days after the first phosphine peak occurred under anaerobic incubation. Statistical treatments of the results show that for the sample with phosphonoacetic acid added the PEARSON or CORREL correlation coefficient between methane and phosphine is 0.983 , while the correlation coefficient for the control sample is 0.500 . The $\mathrm{PH}_{3}$ mean emission rate is about 2.2 ng $\mathrm{PH}_{3} \mathrm{~kg}^{-1} \mathrm{~h}^{-1}$.

The presence of organic compounds containing $\mathrm{C}-\mathrm{P}$ bonds may be crucial for the occurrences of high phosphine levels. When microorganisms under anaerobic
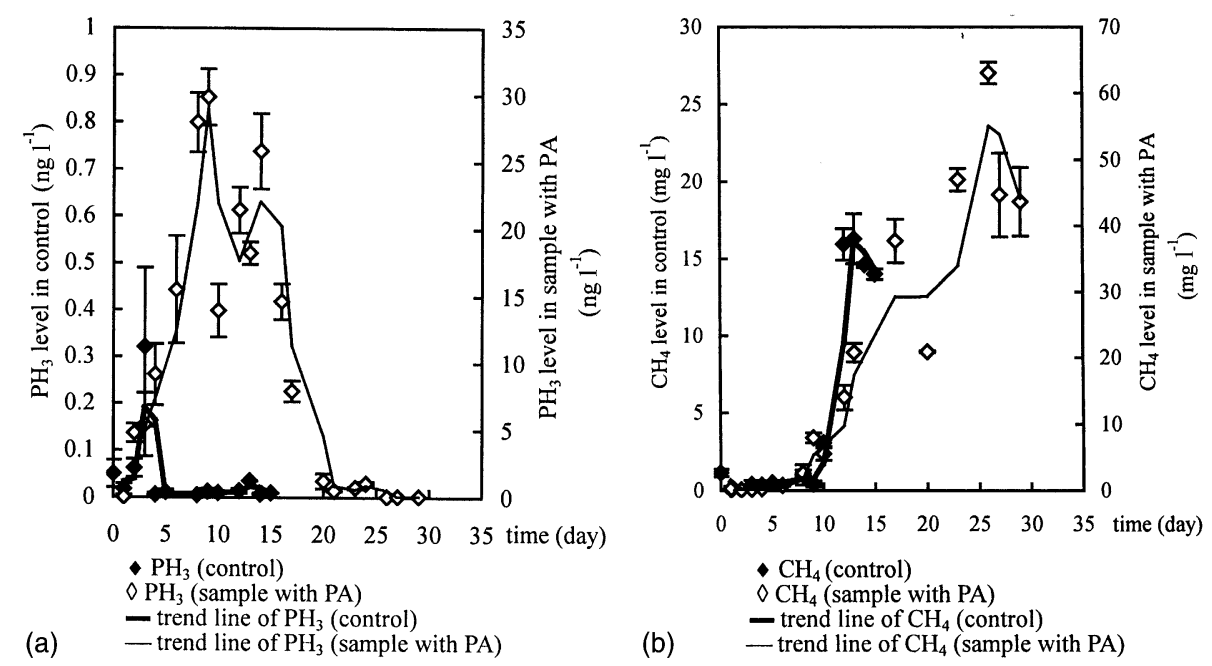

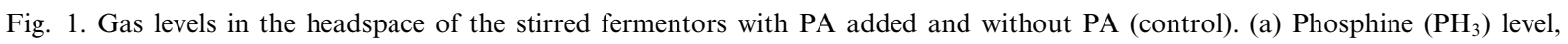
(b) methane $\left(\mathrm{CH}_{4}\right)$ level. 
conditions degrade these C-P compounds, both $\mathrm{PH}_{3}$ and $\mathrm{CH}_{4}$ might be formed. This point will be discussed again in the next section.

\subsection{Matrix-bound phosphine and methane in the cultivat- ing soil samples}

The total phosphorus content in our paddy soil is $0.96 \mathrm{mg} \mathrm{P} \mathrm{g}^{-1} \mathrm{dw}$. The addition of 1.03-g phosphonoacetic acid to $3 \mathrm{~kg}$ of paddy soil in the fermentor is equivalent to an increment of $0.076 \mathrm{mg} \mathrm{P} \mathrm{g}^{-1} \mathrm{dw}$. In other words, the total phosphorus in the sample was increased by $8 \%$, as compared to the control sample. After 1-month anaerobic incubation, the matrix-bound phosphine content in the soil sample with phosphonoacetic acid addition became $8371.9 \mathrm{mg} \mathrm{Pg}^{-1} \mathrm{dw}$. It means there was a 90 -fold increment in matrix-bound phosphine as compared with the control, or an 800 -fold increment as compared with the dry paddy soil without incubation (see Table 2).

Jenkins et al. (2000) reported that bacteria (such as Escherichia coli, Salmonella gallinarum etc.) and solvent fermentors (Colstridium sporogenes, etc.) could generate phosphine, and these fermentative bacteria participate in a multi-stage process of methanogenesis in nature. Probably, phosphine and methane are produced at different stages of fermentation.
From Fig. 2, we can see that phosphonoacetic acid has a double-edge effect. Addition of small amounts of phosphonoacetic acid (100 mg phosphonoacetic acid in 40-g soil, dry weight) promoted $\mathrm{PH}_{3}$ and $\mathrm{CH}_{4}$ formation in the soil sample, while larger amounts of phosphonoacetic acid (200 and $300 \mathrm{mg}$ phosphonoacetic acid in 40 g soil, dry weight) inhibited $\mathrm{PH}_{3}$ and $\mathrm{CH}_{4}$ generation. Inhibition might be caused either by the toxicity of phosphonoacetic acid itself, or by the acidity of this fairly strong acid. Under different $\mathrm{pH}$ values of incubated soil, the amount of matrix-bound $\mathrm{PH}_{3}$ generated was different.

Fig. 3 shows the effect of $\mathrm{pH}$ on matrix-bound phosphine formation. The highest matrix-bound $\mathrm{PH}_{3}$ content occurred under a neutral condition that is suitable for microbial reproduction. Under an alkaline condition, the matrix-bound $\mathrm{PH}_{3}$ level is lower. The matrix-bound phosphine level in acidic soil was found to be the lowest.

\subsection{Sequential fractionation of reactive phosphorus}

Phosphorus release is a function of the quantities and distribution of various phosphorus fractions in the soil. It is also a function of the degree of saturation of exchangeable phosphorus. It is linked closely to the intensity of biological processes in soil and water, as well as to the hydrological conditions (Jansson et al., 1988). It was

Table 2

Matrix-bound $\mathrm{PH}_{3}$ and $\mathrm{CH}_{4}$ levels in stirred samples

\begin{tabular}{llll}
\hline Sample & $\begin{array}{l}\text { Matrix-bound } \mathrm{PH}_{3} \\
\left(\mathrm{pg} \mathrm{g}^{-1} \mathrm{dw}\right) \pm \text { s.d. }\end{array}$ & $\begin{array}{l}\text { Matrix-bound } \mathrm{CH}_{4} \\
\left(\mathrm{mg} \mathrm{g}^{-1} \mathrm{dw}\right) \pm \text { s.d. }\end{array}$ & Reference \\
\hline Soil sample with PA & $8371.9 \pm 923.9(n=4)$ & $10.1 \pm 2.0(n=6)$ & This work \\
Soil sample without PA (control) & $91.2 \pm 11.3(n=5)$ & $43.2 \pm 5.1(n=3)$ & This work \\
Dry soil sample from the same site without incubation & 10.4 & - & Han et al. (2000) \\
\hline
\end{tabular}
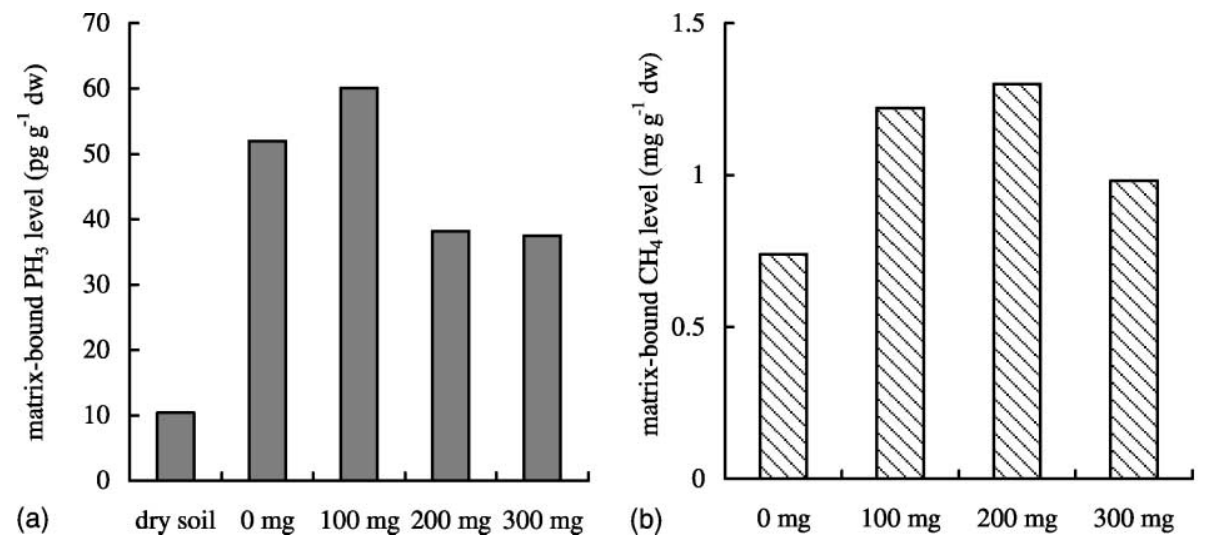

Fig. 2. Matrix-bound $\mathrm{PH}_{3}$ and $\mathrm{CH}_{4}$ in unstirred samples with different amounts of $\mathrm{PA}$ added. (a) Matrix-bound $\mathrm{PH}_{3}$ level, (b) matrixbound $\mathrm{CH}_{4}$ level. 


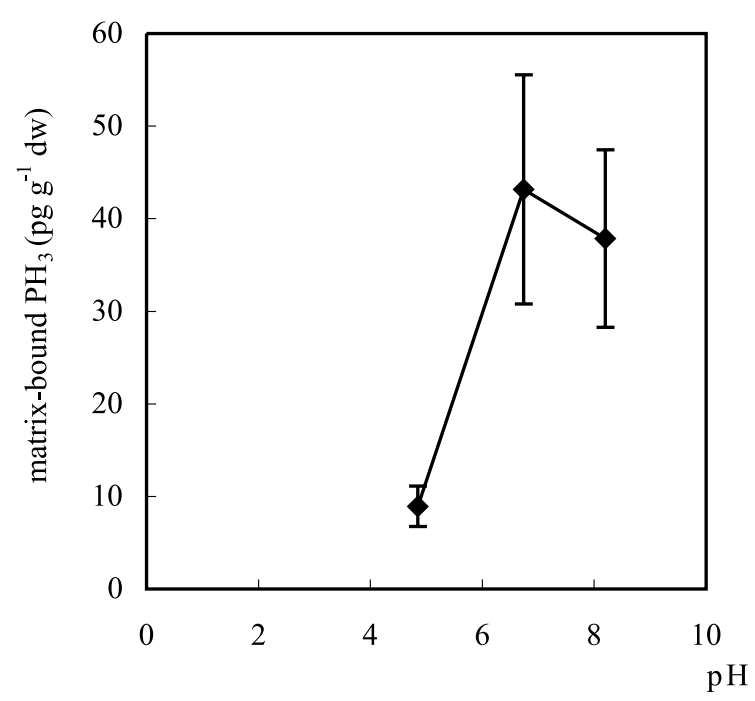

Fig. 3. Matrix-bound $\mathrm{PH}_{3}$ level in unstirred samples under different $\mathrm{pH}$ values.

reported, that the 'reductant' soluble phosphorus species, which were extracted mainly from the iron hydroxide surface and the buffered dithionite reactive phosphorus (BD-RP) fraction of the soil sample, may play a key role in phosphorus release (Zinder and Stumm, 1985; Psenner and Pucsko, 1988; Fu et al., 2000).

It was shown in Fig. 4 and Table 3 that $\mathrm{H}_{2} \mathrm{O}-\mathrm{RP}$ and $\mathrm{BD}-\mathrm{RP}$ levels under anaerobic conditions were obviously higher than those in dry soils without incubation.

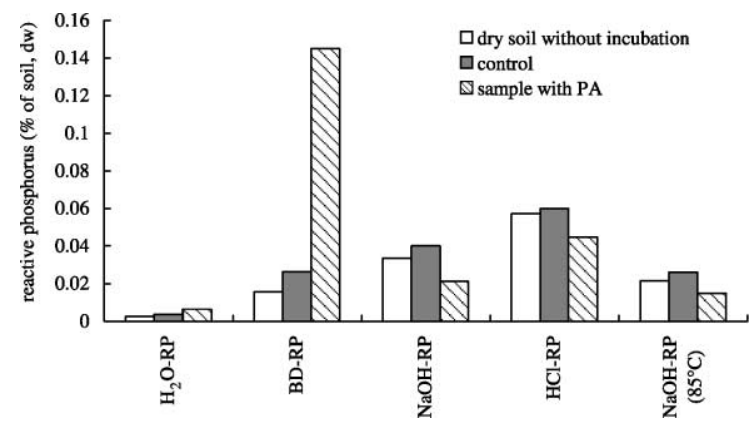

Fig. 4. Reactive phosphorus extracted from stirred samples with PA and without PA (control).
When organic phosphorus compounds containing C-P bonds like phosphonoacetic acid were added, the amount of BD-RP fraction extracted by buffered sodium dithionite solution increased dramatically. The share of the BD-RP fraction in Tot-RP for stirred samples was as high as $62.5 \%$. On the contrary, the $\mathrm{NaOH}-\mathrm{RP}$ fraction decreased.

For unstirred incubation samples, the results on reactive phosphorus levels are shown in Fig. 5 and Table 4. They are similar to those stirred samples with the only difference that the BD-RP contents were not as high as in the stirred samples upon phosphonoacetic acid addition. Sondergaard et al. (1992) also reported that agitation or disturbance of sediments promoted phosphorus release. They found that wind-induced resuspension of sediments occurred frequently in shallow and eutrophic lakes, and that phosphorus release from disturbed sediments could be 20-30 times higher than the release from undisturbed sediments.

Sridharan and Lee (1974) pointed out that mineralization of organic phosphorus is one of the mechanisms of phosphorus release. Daughton et al. (1979) first reported that bacteria caused C-P bond cleavage to yield alcohols, alkanes and phosphate. In our case, we found an increment in phosphine and methane levels both in the headspace and in the soil samples upon incorporation of a compound with a $\mathrm{C}-\mathrm{P}$ bond. The correlation between matrix-bound $\mathrm{PH}_{3}$ levels and various fractions of reactive phosphorus, as well as that between matrixbound $\mathrm{CH}_{4}$ levels and fractions of reactive phosphorus, are presented in Table 5 .

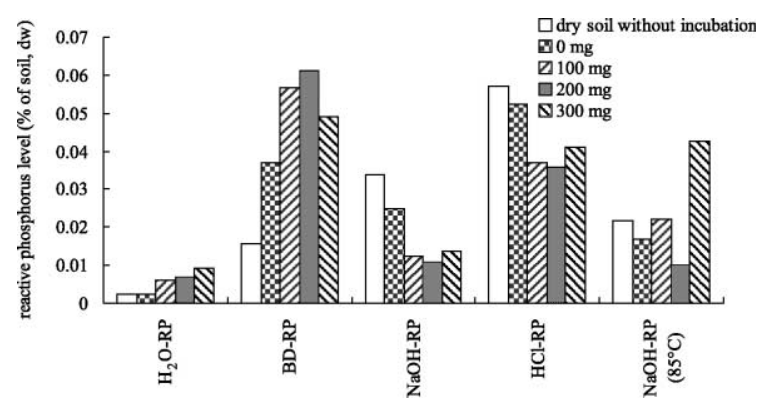

Fig. 5. Reactive phosphorus extracted from unstirred samples with different amounts of PA added.

Table 3

Shares of fractionated reactive phosphorus in total reactive phosphorus (Tot-RP) of stirred samples (\%)

\begin{tabular}{llllrr}
\hline Sample & $\mathrm{H}_{2} \mathrm{O}-\mathrm{RP}$ & $\mathrm{BD}-\mathrm{RP}$ & $\mathrm{NaOH}-\mathrm{RP}$ & $\mathrm{HCl}-\mathrm{RP}$ & $\mathrm{NaOH}-\mathrm{RP}\left(85^{\circ} \mathrm{C}\right)$ \\
\hline Sample with PA & 2.7 & 62.5 & 9.1 & 19.2 & 6.5 \\
Sample without PA (control) & 2.3 & 16.9 & 25.6 & 38.5 & 16.6 \\
Dry soil sample from the same site without incubation & 1.9 & 12.0 & 25.7 & 43.9 & 16.5 \\
\hline
\end{tabular}


Table 4

Shares of fractionated reactive phosphorus in total reactive phosphorus (Tot-RP) of unstirred soil samples (\%)

\begin{tabular}{lllrrr}
\hline Amount of PA added & $\mathrm{H}_{2} \mathrm{O}-\mathrm{RP}$ & $\mathrm{BD}-\mathrm{RP}$ & $\mathrm{NaOH}-\mathrm{RP}$ & $\mathrm{HCl}-\mathrm{RP}$ & $\mathrm{NaOH}-\mathrm{RP}\left(85{ }^{\circ} \mathrm{C}\right)$ \\
\hline $0 \mathrm{mg}$ & 2.0 & 27.8 & 18.6 & 39.1 & 12.6 \\
$100 \mathrm{mg}$ & 4.6 & 42.2 & 9.2 & 27.7 & 16.4 \\
$200 \mathrm{mg}$ & 5.6 & 48.9 & 8.7 & 28.8 & 8.0 \\
$300 \mathrm{mg}$ & 6.0 & 31.5 & 8.8 & 26.3 & 27.4 \\
Dry soil sample from the same site without incubation & 1.9 & 12.0 & 25.7 & 43.9 & 16.5 \\
\hline
\end{tabular}

Table 5

Correlation between matrix-bound $\mathrm{PH}_{3} / \mathrm{CH}_{4}$ concentrations and reactive phosphorus (RP) in unstirred samples

\begin{tabular}{|c|c|c|c|c|c|c|}
\hline \multirow[t]{2}{*}{ Fractions of RP } & \multicolumn{3}{|c|}{ Equation for $\mathrm{PH}_{3}^{*}: y_{1}=a \cdot \mathrm{e}^{b x}$} & \multicolumn{3}{|c|}{ Equation for $\mathrm{CH}_{4}^{*}: y_{2}=c \cdot \mathrm{e}^{d x}$} \\
\hline & $a$ & $b$ & $R_{1}^{2}$ & $c$ & $d$ & $R_{2}^{2}$ \\
\hline $\mathrm{H}_{2} \mathrm{O}-\mathrm{RP}$ & 20.502 & 92.736 & 0.1588 & 0.7511 & 51.251 & 0.3190 \\
\hline BD-RP & 9.0134 & 30.346 & 0.6357 & 0.2996 & 24.346 & 0.9948 \\
\hline $\mathrm{NaOH}-\mathrm{RP}$ & 92.332 & -51.97 & 0.5394 & 1.8682 & -38.025 & 0.9029 \\
\hline HCl-RP & 293.68 & -48.08 & 0.4334 & 4.2439 & -33.894 & 0.9635 \\
\hline $\begin{array}{l}\mathrm{NaOH}-\mathrm{RP} \\
\left(85^{\circ} \mathrm{C}\right)\end{array}$ & 35.659 & -1.8691 & 0.0011 & 1.1217 & -3.4639 & 0.0368 \\
\hline
\end{tabular}

${ }^{*} y_{1}$ is the matrix-bound $\mathrm{PH}_{3}$ concentration in $\mathrm{pg} \mathrm{g}^{-1} \mathrm{dw} ; y_{2}$ is the matrix-bound $\mathrm{CH}_{4}$ concentration in $\mathrm{mg} \mathrm{g}{ }^{-1} \mathrm{dw} ; x$ is the share of reactive phosphorus in soil (\% $\mathrm{dw}) ; R_{1}$ and $R_{2}$ are the regression coefficients.

Judging from Table 5, we found that matrix-bound $\mathrm{PH}_{3}$ and $\mathrm{CH}_{4}$ levels have a positive exponential correlation with the BD-RP fraction, and a negative exponential correlation with the $\mathrm{NaOH}-\mathrm{RP}$ and $\mathrm{HCl}-\mathrm{RP}$ fractions. However, the $\mathrm{H}_{2} \mathrm{O}-\mathrm{RP}$ and $\mathrm{NaOH}-\mathrm{RP}\left(85^{\circ} \mathrm{C}\right)$ fractions have no correlation with the matrix-bound $\mathrm{PH}_{3}$ and $\mathrm{CH}_{4}$ levels.

This implies hitherto unknown but important phosphorus cycling processes, which might have both positive and negative effects on the environment. In view that phosphine is an intermediate product of anaerobic processes in soil, its subsequent oxidation to phosphoric acid is actually an activation process of soil phosphorus originally unavailable to plants. This is an overlooked positive aspect of phosphine on plant growth. Phosphine is also a reactive atmospheric trace gas, which competes with methane and other greenhouse gases for hydroxyl radicals, because $\mathrm{PH}_{3}$ reacts quickly with hydroxyl radicals in the atmosphere (Fritz et al., 1982), and thus enhances an indirect greenhouse effect, or the so-called coupling effect (Prinn, 1994). On the other hand, phosphine itself is a toxic substance, which inhibits the growth of soil microorganisms and damages crop roots. These toxic effects would not only influence the emission fluxes of other greenhouse gases from soil, but also could cause disturbance in the rhizosphere. Matrixbound phosphine in the sediment of water bodies might cause a sudden release of reactive phosphorus and hence eutrophication, if the sediment is brought to the surface layers by upward water current or anthropogenic agitation.

\section{Conclusions}

$\mathrm{PH}_{3}$ and $\mathrm{CH}_{4}$ emissions in paddy soil increased with the addition of phosphonoacetic acid, a biogenic compound containing a carbon-phosphorus bond. Mixing and agitation promoted the formation of phosphine. Upon the introduction of phosphonoacetic acid into incubated soil, both BD-RP and $\mathrm{NaOH}-\mathrm{RP}$ fractions underwent obvious changes. The matrix-bound phosphine level in the BD-RP fraction increased abruptly upon stirring. A positive correlation was observed between matrix-bound $\mathrm{PH}_{3} / \mathrm{CH}_{4}$ levels and the BD-RP content. The NaOH-RP fraction, which contains the iron-bound phosphorus, had a negative correlation with matrix-bound phosphine and methane.

\section{Acknowledgements}

This work is financially supported by the Chinese Natural Science Foundation under the contract no. 39790100. We appreciate the State Key Laboratory for Environmental Aquatic Chemistry for allowing us to use their equipment.

\section{References}

Barrenscheen, H.K., Beckh-Widmanstetter, H.A., 1923. Über Bakterielle Reduktion organisch gebundener Phosphorsäure. Biochemische Zeitschrift 140, 279-283. 
Bayer, E., Gugel, K.H., Hägele, K., Hagenmaier, H., Jessipow, S., König, W.A., Zähner, H., 1972. Metabolic products of microorganisms. 98. Phosphinothricin and phosphinothricylalanylalanine. Helvetica Chimica Acta 55, 224-239.

Cao, H.F., Liu, J.A., Zhuang, Y.H., 2000. Emission sources of atmospheric phosphine and the simulation of phosphine formation. Science in China (Series B) 43, 162-168.

Cook, A.M., Daughton, C.G., Alexander, M., 1978. Phosphonates utilization by bacteria. Journal of Bacteriology 133, 85-90.

Daughton, C.G., Cook, A.M., Alexander, M., 1979. Bacterial conversion of alkylphosphonates to natural products via carbon-phosphorus bond cleavage. Journal of Agricultural and Food Chemistry 27, 1375-1382.

Devai, I., Delaune, R.D., 1995. Evidence for phosphine production and emission from Louisiana and Florida marsh soils. Organic Geochemistry 23, 277-279.

Devai, I., Felfody, L., Wittner, I., 1988. Detection of phosphine: new aspects of the phosphorus cycle in the hydrosphere. Nature 333, 343-345.

Eismann, F., Glindemann, D., Bergmann, A., Kuschk, P., 1997a. Soils as source and sink of phosphine. Chemosphere 35, 523-533.

Eismann, F., Glindemann, D., Bergmann, A., Kuschk, P., 1997b. Balancing phosphine in manure fermentation. Journal of Environmental Science and Health B 32, 955968.

Eismann, F., Glindemann, D., Bergmann, A., Kuschk, P., 1997c. Effect of free phosphine on anaerobic digestion. Water Research 31, 2771-2774.

Fritz, B., Lorenz, K., Steinert, W., Zellner, R., 1982. Laboratory kinetic investigations of the tropospheric oxidation of selected industrial emissions. In: Versino, B., Ott, H. (Eds.), Proceedings of the Second European Symposium on Physico-Chemical Behaviour of Atmospheric Pollutants. D. Reidel Publishing Company, Dordrecht, Holland, pp. 192-202.

Fu, Y.Q., Zhou, Y.Y., Li, J.Q., 2000. Sequential fractionation of reactive phosphorus in the sediment of a shallow eutrophic lake-Donghu Lake, China. Journal of Environmental Sciences 12, 57-62.

Gassmann, G., 1994. Phosphine in fluvial and marine hydrosphere. Marine Chemistry 45, 197-205.

Gassmann, G., Schorn, F., 1993. Phosphine from harbor surface sediment. Naturwissenschaften 80, 78-80.

Glindemann, D., Bergmann, A., 1995. Spontaneous emission of phosphine from animals slurry treatment processing. Zentralblatt für Hygiene und Umweltmedizin 198, 49-56.

Glindemann, D., Bergmann, A., Stottmeister, U., Gassmann, G., 1996a. Phosphine in the lower terrestrial troposphere. Naturwissenschaften 83, 131-133.

Glindemann, D., Stottmeister, U., Bergmann, A., 1996b. Free phosphine from the anaerobic biosphere. ESPR-Environmental Science \& Pollution Research 3, 17-19.

Han, S.H., Zhuang, Y.H., Liu, J.A., Glindemann, D., 2000. Phosphorus cycling through phosphine in paddy fields. The Science of Total Environment 258, 195-203.

Hilderbrand, R.L., Henderson, T.G., 1983. Phosphonic acids in nature. In: Hilderbrand, R.L. (Ed.), The Role of Phosphonates in Living Systems. CRC Press, Boca Raton, Florida, pp. 5-29.
Hilderbrand, R.L., Henderson, T.O., Glonek, T., Myers, T.C., 1973. Isolation and characterization of a phosphonic acid rich glycoprotein preparation from Metridium dianthus. Biochemistry 12, 4756-4762.

Horiguchi, M., Kandatsu, M., 1959. Isolation of 2-aminoethane phosphonic acid from rumen protozoa. Nature 184, 901-902.

Iverson, W.P., 1968. Corrosion of iron and formation of iron phosphide by Desulfovibrio desulfuricans. Nature 217, 12651267.

Jansson, M., Enell, M., Fleischer, S., 1988. Phosphorus: origin, characteristics, and function in lakes. Hydrobiologia 170 , 177-189.

Jenkins, R.O., Morris, T.A., Craig, P.J., Ritchie, A.W., Ostah, N., 2000. Phosphine generation by mixed- and monosepticcultures of anaerobic bacteria. Science of the Total Environment $250,73-81$.

Korn, E.D., Dearborn, D.G., Fales, H.M., Sokoloski, E.A., 1973. Phosphonoglycan. A major polysaccharide constituent of the amoeba plasma membrane contains 2-aminoethylphosphonic acid. Journal of Biological Chemistry 248, 2257-2259.

Li, Y.K., Jiang, B.P., Yuan, K.N., 1984. Handbook of AgroChemistry Analysis. Science Press, Beijing (in Chinese).

Liu, J.A., Cao, H.F., Zhuang, Y.H., Kuschk, P., Eismann, F., Glindemann, D., 1999. Environmental analysis of phosphine in a paddy field and from other places during summer temperate climate in Beijing, China. Water, Air \& Soil Pollution 166, 597-604.

Mastalerz, P., 1984. Biosynthesis of phosphonates. In: Zalewski, R.I., Skolik, J.J. (Eds.), Studies in Organic Chemistry, vol. 20: Natural Products Chemistry. Elsevier, Amsterdam, pp. 171-184.

Murphy, J., Riley, J.P., 1962. A modified single solution method for the determination of phosphate in natural waters. Analytical Chemica Acta 27, 31-36.

Prinn, R.G., 1994. The interactive atmosphere: global atmospheric-biospheric chemistry. Ambio 23, 50-61.

Psenner, R., Pucsko, R., 1988. Phosphorus fractionation: advantages and limits of the method for the study of sediment phosphorus origins and interactions. Ergebnisse der Limnologie 30, 43-59.

Rosenberg, H., 1973. Phosphonolipids. In: Ansell, G.B., Hawthorne, J.N., Dawson, R.M.C.D. (Eds.), Form and Function of Phosphonolipids. Elsevier, Amsterdam, pp. 333-344.

Sondergaard, M., Kristensen, P., Jeppeaen, E., 1992. Phosphorus release from resuspended sediment in the shallow and wind-exposed Lake Arreso, Denmark. Hydrobiologia 228, 91-99.

Sridharan, N., Lee, G.F., 1974. Phosphorus studies in lower Green Bay, Lake Michigan. Journal of Water Pollution Control Federation 46, 684-696.

Thompson, S.N., Lee, R.W.K., 1985. Phosphorus-31 studies on adenylates and other phosphorus metabolites in the schistosome vector Biomphalaria glabrata. Journal of Parasitology 71, 652-663.

Tsubota, G., 1959. Phosphate reduction in the paddy field. I. Soil and Plant Food 5, 10-15.

Zinder, B., Stumm, W., 1985. Dissolution of iron (III) oxides; its significance in sea and soil. Chimia 39, 80-288. 